\title{
Öğrenci Başarısının Okul, Öğretmen ve Aileyle İlgili Değişkenler Açısından İncelenmesi*
}

\author{
Examination of Student Achievement in terms of School, Teacher, and \\ Family-Related Variables \\ Züleyha AKKURT** $\quad$ Esra KARABAĞ KÖSE**** \\ - Geliş Tarihi: 08.08.2018 • Kabul Tarihi: 24.06.2019 • Yayın Tarihi: 06.07.2019
}

\begin{abstract}
$\ddot{\mathbf{O} z}$
Bu araştırmanın amacı, okul, öğretmen ve aile ile ilgili değişkenlerin öğrencilerin okul başarısı üzerindeki etkilerinin karşılaştırmalı olarak incelenmesidir. İlişkisel tarama modelinde tasarlanan araştırmaya Balıkesir merkez ve ilçelerindeki 12 farklı lisede öğrenim gören 698 öğrenci katılmıştır. Araştırmada ölçme aracı olarak, Liselerde Okul Yaşam Kalitesi Ölçeği ve Öğretmen Sınıf Liderliği Ölçeği kullanılmıştır. Verilerin analizinde korelasyon ve çoklu doğrusal regresyon analizleri ile yapısal regresyon modelinden yararlanılmıştır. Doğrusal regresyonla oluşturulan modeller, öğrencilerin demografik özelliklerinin ve öğretmen sınıf liderliği algılarının okul başarıları üzerinde etkili olduğunu ortaya koymaktadır. Buna karşın öğrencilerin okul yaşam kalitesi algılarının okul başarısı üzerindeki etkisi istatistiksel olarak anlamlı bulunmamıştır. Kontrol değişkenlerinin de dâhil edildiği regresyon analizi sonuçları, okul başarısı üzerinde en etkili değişkenin sosyoekonomik düzey olduğunu göstermektedir. Sosyoekonomik düzeyi takip eden en güçlü değişkenler ise okul ve öğretmen sınıf liderliği değişkenleridir.
\end{abstract}

Anahtar sözcükler: öğretmen sınıf liderliği, okul yaşam kalitesi, sosyoekonomik düzey, okul başarısı

Atıf:

Akkurt, Z., ve Karabağ Köse, E. (2019). Öğrenci başarısının okul, öğretmen ve aileyle ilgili değişkenler açısından incelenmesi. Pamukkale Üniversitesi Eğitim Fakültesi Dergisi, 47,1-16. doi: 10.9779/pauefd.451853.

\footnotetext{
* Çalışma, birinci yazarın yüksek lisans tez çalışması kapsamında hazırlanmış olup, 10-12 Mayıs 2018 tarihlerinde, 13. Uluslararası Eğitim Yönetimi Kongresi'nde sözlü bildiri olarak sunulmuştur.

** Öğretmen, Milli Eğitim Bakanlığı, ORCID ID: 0000-0001-6333-0486, zuleyha0610@ gmail.com

**** Dr. Öğretim Üyesi, Kırıkkale Üniversitesi, ORCID ID: 0000-0003-1367-7793, esrakarabag@ gmail.com
} 


\begin{abstract}
This study aims to compare the effects of school, teacher, and family-related variables on students' academic performance. The study was designed as a relational screening model and included 698 students from 12 high schools in both the city-center and the surrounding townships of Balıkesir Province, Turkey. The measurement tools utilized in this study were the Quality of Life in High Schools Scale and the Teacher Classroom Leadership Scale. In addition to conducting a correlation and multiple regression analysis, a structural regression model was used to analyze data. The linear regression models reveal that while students' demographic characteristics and teacher classroom leadership perceptions have a significant impact on students' academic performance, students' perceptions of school life quality were found not to be statistically significant. The results of the regression analysis in which control variables were included indicate that families' socioeconomic level followed by school and teacher classroom leadership have the greatest impact of all variables on students' academic performance.
\end{abstract}

Keywords: teacher classroom leadership, school life quality, socioeconomic level, school achievement.

\title{
Cited:
}

Akkurt, Z., \& Karabağ Köse, E. (2019). Examination of student achievement in terms of school, teacher, and family-related variables. Pamukkale Üniversitesi Ĕgitim Fakültesi Dergisi, 47,1-16. doi: 10.9779/pauefd.451853. 


\section{Giriş}

Okul, öğretmen ve aile değişkenleri öğrencilerin okul başarısının en temel belirleyicileri arasındadır. Özellikle PISA araştırmalarının ortaya koyduğu sonuçlar, öğrenci başarısı üzerindeki en etkili faktörlerin aile ve öğrenci özellikleri ile öğretmen ve okul faktörleri olduğunu göstermektedir (OECD, 2017; Sarıer, 2016; Yıldırım, 2009). Diğer taraftan okul ve öğretmen faktörleri ile ilgili olarak, öğretim süreçleri ve öğrenci başarısı üzerindeki etkileri bakımından son 30 yılda araştırmacıların yoğun bir şekilde ilgisini çeken önemli değişkenler arasında öğrencilerin okul yaşam kalitesi ve öğretmen liderliği değişkenleri yer almaktadır. (Lipesa, 2018; Mok ve Flynn, 1997; Sugg, 2013; Wenner ve Campbell, 2017; York-Barr ve Duke, 2004). Bu araştırmada, okul faktörüyle ilgili olarak okul yaşam kalitesi, okul türü ve okul; ögretmen faktörüyle ilgili olarak öğretmen sınıf liderliği ve aile faktörüyle ilgili olarak da ailelerin sosyoekonomik düzeyi değişkenlerinin öğrencilerin okul başarısı üzerindeki etkileri, oluşturulan bütüncül modelle karşılaştırmalı olarak incelenmiştir.

\section{Okul Yaşam Kalitesi}

Okul yaşam kalitesi, öğrencilerin eğitimle ulaşması hedeflenen akademik, sosyal ve psikolojik kazanımlara en üst düzeyde ulaşabilmesi ve öğrenci memnuniyetinin sağlanması ile ilgili bir kavramdır. Karatzias, Power ve Swanson'a (2001) göre, okul yaşam kalitesinin en önemli göstergesi, öğrencilerin okul yaşamına etkin katılımları yoluyla genel iyi olma hallerinin gerçekleştirilmesidir. Okul yaşamı, öğrencilerin kendilerini mutlu hissetmelerine katk1 sağlayacak etkiler oluşturabileceği gibi, öğrenciler üzerinde olumsuz etkiler de oluşturabilir. Olumlu davranış geliştirmeye katkı sağlayan okul yaşam kalitesi, öğrencilerin sosyal hayatta başarılı olmalarını sağlayacak ve toplumsal uyumlarını destekleyecektir (Bilgiç, 2009; Demir, Kaya ve Metin, 2012). Okulların öğrencinin bireysel ve toplumsal kişiliğinin oluşmasında ve yasa, kural, norm, davranış kuralları ve toplumsal yaşama uyumun öğretilmesindeki sorumlulukları, okul yaşam kalitesinin önemini artırmaktadır (Argon ve Kösterelioğlu, 2009).

Epstein ve Mcpartland (1976) okul yaşamın kalitesini genel olarak okuldan memnuniyet, okul çalışmalarına bağl1lık ve öğretmenlere yönelik tutum olmak üzere üç boyuttan oluştuğunu ifade etmektedirler. Sarı (2012) tarafından yapılan çalışma ise, okul yaşam kalitesinin; öğretmenler, öğrenciler, okula yönelik duygular, okul yönetimi ve statü olmak üzere beş alt boyutta ele alınabileceğini göstermektedir. Buna göre, öğretmenler alt boyutu, öğretmenöğrenci iletişiminin niteliği ve öğretmenlerin kendilerini geliştirme düzeyleri ile ilgilidir. Ögrenciler alt boyutu ise öğrenciler arasındaki iletişimin niteliği ile ilgilidir. Okula yönelik duygular alt boyutu, öğrencilerin okullarıyla gurur duyması, okula yönelik sevgileri gibi duyguları ele almaktadır. Okul yönetimi alt boyutunda, okul yöneticilerinin öğrencilerle olan iletişimlerinin niteliği, katılımcı yönetim tarzları ve öğrencilere olan ilgileri vurgulanmaktadır. Son olarak statü alt boyutu ise, öğrencilerin birer birey olarak kendilerini okulda değerli ve önemli hissetmeleri ile ilgilidir. Bu beş alt boyut bir arada öğrencilerin okul yaşam kalitesi algılarını tanımlamaktadır.

Farklı okul türlerinde yapılan ampirik araştırmalar, öğrencilerin sosyoekonomik özellikleri ve aile özellikleri, cinsiyet, sınıf büyüklüğü, akademik başarı, okul devamlılığı gibi değişkenlerin öğrencilerin okul yaşam kalitesi ile yakın bir ilişki içerisinde olduğunu göstermektedir (Ereş ve Bilasa, 2017; Leonard, 2002; Özdemir, Kılınç, Öğdem ve Er, 2013). 
Öğretmen öğrenci etkileşimi ve sınıf ortamındaki öğrenci deneyimleri, öğrencilerin okul yaşam kalitesi üzerinde etkili olan en önemli faktörler arasındadır (Mok ve Flynn, 2002; Sarı, 2012). Epstein ve Mcpartland'a (1976) göre, okul yaşam kalitesinin önemli belirleyicileri; okulun sosyal yapısı, sınıf içi etkinliklere katılım ve öğretmenlerle olan etkileşimdir. Bu bağlamda, öğrencilerin okul yaşam kalitesinin, öğretmen etkileşimi ile yakından ilgili olan bir başka önemli değişken olan öğretmen sınıf liderliği ile ilişkilerinin incelenmesi önemli görülmüştür.

\section{Öğretmen Sınıf Liderliği}

Okul liderliği yaklaşımları, 90'lı yıllardan sonra, okul yöneticisi ile özdeşleştirilen liderliğin özellikle öğretmenlerle paylaşılmasının tartışıldığı bir dönüşüm geçirmiştir (Avolio, Walumbwa ve Weber, 2009; Karabağ-Köse, 2018). Bu bağlamda en yoğun tartış1lan kavramlardan birisini de öğretmen liderliği kavramı oluşturmuştur (Wenner ve Campbell, 2017; York-Barr ve Duke, 2004). Liderlik, genel anlamı ile takipçileri belirli amaçları gerçekleştirmek için bir araya getirecek ve harekete geçirecek bilgi ve yeteneklerinin toplamı olarak tanımlanmaktadır (Çelik, 2017). Bu tanımlama öğretmenler açısından, öğrencileri eğitim ve öğretim sürecinin amaçları doğrultusunda harekete geçirecek bilgi ve yetenekler olarak yorumlanabilir. Öğretmen liderliği, okul düzeyinde meslektaşlara yönelik, sınıf düzeyinde ise öğrencilere yönelik farklı liderlik rol ve davranışlarını içermektedir (Beycioğlu ve Aslan, 2010; Karabağ-Köse, 2018; Watt, Huerta ve Mills, 2010).

Bir sınıf lideri olarak öğretmenin öğrencilere yapmış olduğu liderlik, eğitim yönetimi alanyazınının güncel tartışma konularından birisidir (Ertesvåg, 2009; Karabağ-Köse, 2018; Muijs ve Harris, 2007; Pounder, 2006; Wenner ve Campbell, 2017). Sınıftaki eğitim ve öğretim süreçlerinde öğretmen, hedefleri ve bu hedeflere ulaşmayı sağlayacak strateji ve teknikleri belirlemekte, gerekli sinerjiyi oluşturmakta ve tüm süreci değerlendirerek sınıfı yönetmektedir (Bakioğlu, 1998). Dolayısıyla küçük bir örgüt özelliği taşıyan sınıfta, öğretmenin öğrencilerini ortak amaçlar için harekete geçirebilmesi, onun sınıf liderliği rollerinin çerçevesini oluşturmaktadır. Öğrencilerin en önemli sosyal destek kaynakları arasında yer alan öğretmenlerin, akademik süreçlerin yanı sıra öğrencilerin davranışsal ve sosyal problemleri ile ilgilenmeleri ve onlara sosyal destek sağlamaları da gerekmektedir (Yıldırım, 2000). Bu bağlamda öğretmenlerin öğrencilere liderliği sadece akademik ve sınıf içi süreçlerle ilgili olarak değil, toplumsal, kültürel, etik vb. pek çok boyutta ayrıntılı olarak ele alınması gereken önemli bir olgudur.

Karabağ-Köse (2019a) tarafından yapılan çalışmada, öğretmen sınıf liderliği kavramı; etkileşim, motivasyon, sınıf içi süreçler ve okul dışı süreçler alt boyutlarında tanımlanmaktadır. Buna göre öğretmen sınıf liderliği, güçlü bir öğretmen-öğrenci etkileşimi, öğrencilerin motive edilmesi, öğretmenin güçlü bir öğretim liderliği göstermesi ve okul dişında da öğrencilerle etkileşimini sürdürmesi ile ilgili öğretmen davranışlarını içermektedir. Öğrencilerin okul yaşam kalitelerinin önemli bir boyutunu da öğretmen etkileşimi oluşturduğu için, öğrenci öğretmen etkileşimini açıklamada önemli bir kavram olarak öne çıkan liderlik olgusunun, okul yaşam kalitesi ile yakından ilişkili olduğu ileri sürülebilir. Öğretmenlerin sınıf liderliğinde olduğu gibi, öğrencilerin okul yaşam kalitelerinin de önemli bir boyutunu sınıf içi süreçlerin ve öğreciöğretmen etkileşiminin niteliği oluşturmaktadır (Epstein ve Mcpartland, 1976; Sarı, 2012). Dolayısıyla öğretmenlerin sınıf liderliği ile öğrencilerin okul yaşam kalitesi ve okul başarısı arasındaki ilişkilerin bütüncül bir yaklaşımla incelenmesi önem taşımaktadır. 


\section{Okul, Öğretmen ve Aile Faktörleri ile Öğrenci Başarısı Arasındaki İlişkiler}

Eğitim sistemi içerisinde öğrenci ile doğrudan etkileşim içinde bulunan ve öğrencilerin ilgi ve ihtiyaçlarını yakından bilen kişiler olan öğretmenlerin, öğrencileri destekleyici bir tutum sergilemeleri öğrencilerin okul başarısı düzeylerini doğrudan etkilemektedir (Yıldırım, 2000). Alanyazında yer alan araştırmalar, öğretmen niteliklerinin öğrencilerin okul başarılarını etkilediğini ortaya koymaktadır. Bu çerçevede okul başarısı üzerinde öğretmen liderliğinin etkisinin önemi birçok araştırma ile ortaya konulmuştur (Kythreotis, Pashiardisve Kyriakides, 2010; Lipesa, 2018; McLean ve Connor, 2015; Sammons, Toth ve Sylva, 2017; Sugg, 2013). Benzeri şekilde okul yaşam kalitesi de, öğrenci başarısını etkileyen önemli değişkenler arasında yer almaktadır (Karalar, Öksüs ve Baba-Öztürk, 2017; Mok ve Flynn, 1997). Bununla birlikte, okul yaşam kalitesi okul içinde öğretmen-öğrenci etkileşimini de içeren geniş bir bağlamda öğrenci memnuniyetine odaklanırken, öğretmen sınıf liderliği, öğretmen öğrenci ilişkilerini okul dış1 süreçleri de içeren daha geniş bir çerçevede incelemektedir. Öğrenci başarısını etkileyen faktörleri geniş bir bağlamda ve çok yönlü olarak ele almayı amaçlayan bu çalışmada okulla ilgili faktörlerin yanı sıra öğretmen faktörünün daha derinlemesine incelenebilmesi için öğretmen sınıf liderliğinin araştırmaya değişken olarak dâhil edilmesi önemli görülmüştür.

Öğrenci başarısı üzerinde etkili olan faktörler arasında yer alan okul faktörü ile ilgili olarak araştırmaya dâhil edilen bir diğer değişken ise okul türü değişkenidir. Uluslararası Öğrenci Başarısını Değerlendirme Programı (OECD, 2017) verileri, başarı puanları açısından okul türleri arasında çok büyük farklılıklar olduğunu ortaya koymaktadır. Buna göre, fen liseleri ve sosyal bilimler liseleri ortalamanın üzerinde puan alırken, anadolu liseleri, imam hatip liseleri, mesleki ve teknik anadolu liseleri ortalamanın altında kalmaktadırlar. Geçmiş PISA sınavlarındaki sonuçlar da, OECD ülkeleri arasında, okul türleri arasındaki başarı farklılaşmasının en yüksek olduğu ülkenin Türkiye olduğunu göstermektedir (EARGED, 2004). Benzeri şekilde öğrenci başarısı üzerindeki etkisi yüksek olan önemli değişkenlerden bir diğeri ailelerin sosyoekonomik düzeyleridir. TIMMS (2015) raporuna göre; sosyoekonomik açıdan dezavantajlı grupların başarı ortalamalarının düşük olduğu görülmektedir. Aynı rapora göre, okul yaşam kalitesi ile yakından ilgili olan, öğretmenlerin iş doyumu, öğrenciler arası akran baskıs1/zorbalı̆̆ı, okula devam, öğrenme ile ilgili tutumlar ve öğretmen yeterlilikleri açısından okulların sahip oldukları kaynakların ve koşulların öğrenci başarısı üzerinde etkili olduğu ve Türkiye'nin bu açıdan dezavantajlı durumda olduğu görülmektedir. Öğrencilerin okul başarıları ile yakın ilişkileri nedeniyle bu çalışmada; okul türü ve ailelerin sosyoekonomik düzeyi değişkenleri de kontrol değişkeni olarak araştırmaya dâhil edilmiştir. Öğrenci başarısı ile ilgili temel değişkenler olan; okul, öğretmen ve aile faktörlerini karşılaştırmalı olarak bütüncül bir modelde incelemesi araştırmanın özgün değerini oluşturmaktadır.

\section{Amaç}

$\mathrm{Bu}$ araştırma, liselerde öğrenci başarısı ile öğretmen sınıf liderliği, öğrencilerin okul yaşam kalitesi algıları ve kontrol değişkenleri (okul, okul türü ve ailelerin sosyoekonomik düzeyi) arasındaki ilişkileri incelemeyi amaçlamaktadır. $\mathrm{Bu}$ amaç çerçevesinde araştırma alt problemleri; (1) Lise öğrencilerinin okul yaşam kalitesi algıları, öğretmen liderliği algıları ve okul başarısı düzeyleri arasındaki ilişkiler nasıldır? (2) Lise öğrencilerinin okul başarısı üzerinde, okul yaşam kalitesi algılarının, öğretmen sınıf liderliği algılarının ve kontrol değişkenlerinin etkileri nasıldır? (3) Lise öğrencilerinin okul başarısı üzerinde; okul, öğretmen 
ve sosyoekonomik düzey değişkenlerinin doğrudan ve dolaylı etkileri nasıldır? şeklinde tanımlanmıştır.

\section{Yöntem}

\section{Evren ve Örneklem}

Araştırma ilişkisel tarama modelinde yapılandırılmıştır. Araştırma evrenini, 2017/2018 eğitim öğretim yılında, Balıkesir merkez ve ilçelerinde bulunan liselerde öğrenim gören 53.565 öğrenci oluşturmaktadır. Örneklem seçiminde küme örnekleme yöntemi ve tesadüfi örnekleme yöntemleri birlikte kullanılmıştır. İlk aşamada İl Milli Eğitim Müdürlüğü ARGE Biriminden alınan bilgiler doğrultusunda okullar sosyoekonomik düzeylerine göre kümelenmiştir. Her kümeden tesadüfi olarak belirlenen eşit sayıda okul araştırmanın çalışma evrenini oluşturmuştur. Örnekleme dahil edilmesine karar verilen okulların müdürleri ile görüşülerek sosyo ekonomik düzey tanımlamaları teyit edilmiştir. Araştırmanın örneklemini, küme örnekleme yöntemi ile belirlenen alt, orta ve üst sosyoekonomik düzeylerde 12 farklı okuldan tesadüfi olarak seçilen öğrenciler oluşturmuştur. Bu çerçevede araştırmaya gönüllü olarak katılım sağlayan 698 öğrenciye ölçek uygulanmıştır. Araştırmaya katılan öğrencilerin demografik özellikleri Tablo 1'de sunulmaktadır.

Tablo 1. Katılımcılara İlişskin Demografik Bilgiler

\begin{tabular}{llll}
\hline Değişkenler & & $n$ & $\%$ \\
\hline \multirow{2}{*}{ Cinsiyet } & Kadın & 343 & 49.1 \\
& Erkek & 355 & 50.9 \\
\hline \multirow{2}{*}{ Sosyoekonomik } & Alt & 109 & 15.6 \\
Düzey & Orta & 359 & 51.4 \\
& Üst & 230 & 33.0 \\
\hline \multirow{3}{*}{ Okul Türü } & Meslek Lisesi & 230 & 33.0 \\
& Anadolu Lisesi & 216 & 30.9 \\
& Fen Lisesi & 165 & 23.6 \\
& İmam Hatip Lisesi & 87 & 12.5 \\
\hline \multirow{3}{*}{ Sinıf Düzeyi } & 9. Sinıf & 153 & 21.9 \\
& 10. Sinıf & 188 & 26.9 \\
& 11. Sinıf & 210 & 30.1 \\
& 12. Sinıf & 147 & 21.1 \\
\hline
\end{tabular}

\section{Veri Toplama Araçları}

Verilerin toplanmasında Sarı (2012) tarafından geliştirilen "Lise Öğrencileri Okul Yaşam Kalitesi Algıları Ölçeği” ile Karabağ-Köse (2019a) tarafindan geliştirilen "Öğretmen Sınıf Liderliği Ölçeği” kullanılmıştır. Öğrenci başarısının değerlendirilmesinde ise 2016/2017 eğitim ögretim yılı yılsonu okul başarı ortalamaları esas alınmıştır.

Lise Öğrencileri Okul Yaşam Kalitesi Ölçeği, 5 faktörden oluşan 32 maddelik bir ölçektir. Sarı (2012) tarafından yapılan çalışma, ölçeğin alt boyutlarına ilişkin güvenirlik değerlerinin .84 ile .69 arasında değiştiğini ortaya koymaktadır. Bu çalışma için tekrar edilen 
analiz sonuçlarına göre güvenirlik değerleri sırasıyla; $.80, .77, .86, .77, .70$ şeklindedir. Ölçeğin özgün faktör yapısı bu çalışmada da doğrulanmış olup, model uyum değerleri $[\chi 2 / s d=2.52$; $\mathrm{GFI}=.90 ; \mathrm{CFI}=.90 ; \mathrm{NFI}=.85 ; \mathrm{RMSEA}=.05]$ şeklindedir.

Öğretmen Sınıf Liderliği Ölçeği, 4 faktörden oluşan 25 maddelik bir ölçektir. KarabağKöse (2019a) tarafından yapılan çalışma, ölçeğin alt boyutlarına ilişkin güvenirlik değerlerinin .73 ile .84 arasında değiştiğini ortaya koymaktadır. Bu çalışma için tekrar edilen analiz sonuçlarına göre güvenirlik değerleri sırasıyla; $.89, .74, .76, .83$ şeklindedir. Ölçeğin özgün faktör yapısı bu çalışmada da doğrulanmış olup, model uyum değerleri $[\chi 2 / s d=2.56$; GFI=.93; CFI=.94; NFI=.91; RMSEA=.05] kabul edilebilir düzeydedir.

\section{Verilerin Analizi}

Araştırmada kullanılan ölçme araçlarına ilişkin geçerlik ve güvenirlik kanıtlarını değerlendirmek üzere açımlayıcı ve doğrulayıcı faktör analizleri yapılmıştır. Araştırma verilerinin normallik ve doğrusallık varsayımlarını karşılama durumları değerlendirilmiştir. $\mathrm{Bu}$ çerçevede, basıklık ve çarpıklık katsayıları incelenmiş, tekli ve çoklu normallik değerlendirmeleri yapılmış, değişkenler arası çoklu bağıntı durumları değerlendirilmiştir. Çalışmada değişkenler arasındaki ilişkileri değerlendirmek üzere korelasyon ve aşamalı çoklu doğrusal regresyon analizleri ile yapısal regresyon modelinden yararlanılmıştır.

\section{Bulgular}

Araştırma değişkenlerine ilişkin betimsel veriler ve basıklık/çarpıklık katsayıları ile değişkenler arasındaki ilişkileri değerlendirmek üzere yapılan korelasyon analizi sonuçları Tablo 2'de yer almaktadir.

Tablo 2. Betimsel İstatistikler, Basıklık/Çarpıklık ve Korelasyon Katsayıları

\begin{tabular}{lrrrrrr}
\hline & OYK & ÖSL & $\bar{X}$ & SS & Çarpıklık & Basıklık \\
\hline Okul Yaşam Kalitesi (OYK) & & & 2.98 & .59 & .122 & -.247 \\
Öğretmen Sınıf Liderliği (ÖSL) & $.650^{*}$ & & 3.09 & .71 & .036 & -.549 \\
Okul Başarısı & $.144 *$ & $.162 *$ & 76.46 & 11.09 & -.807 & -.070 \\
\hline
\end{tabular}

Tablo 2 incelendiğinde, değişkenler arasındaki ilişkilerin pozitif yönde ve anlamlı olduğu görülmektedir. Bununla birlikte değişkenler arası korelasyon değerleri, çoklu bağıntı oluşturacak düzeyde güçlü değildir $\left(r^{2}<.5\right)$. Ayrıca öğretmen sınıf liderliğinin okul başarısı ile ilişkisinin okul yaşam kalitesi değişkenine göre daha yüksek olduğu görülmektedir. Araştırma değişkenlerine ilişkin basıklık ve çarpıklık katsayıları, verinin normal dağılım gösterdiğine işaret etmektedir.

Aşamalı doğrusal regresyon analizinde öncelikle araştırmanın temel değişkenleri olan ögretmen sınıf liderliği ve okul yaşam kalitesi değişkenleri modele dahil edilmiştir. Sonrasında kontrol değişkenleri olarak; okul türü, okul, ailelerin sosyoekonomik düzeyi değişkenleri de sırasıyla modele dahil edilmiş ve alternatif regresyon modelleri aşamalı olarak test edilmiştir. Elde edilen regresyon modellerine ilişkin veriler Tablo 3'de sunulmaktadır. 
Tablo 3. Aşamalı Regresyon Analizi Sonuçları

\begin{tabular}{|c|c|c|c|c|c|c|}
\hline Model & Yordayıcı Değişkenler & B & $\begin{array}{r}\text { Standart } \\
\text { Hata }\end{array}$ & Beta & $t$ & $p$ \\
\hline \multirow{2}{*}{1} & (Sabit) & 78.618 & 1.988 & & 39.540 & .000 \\
\hline & ÖSL & 2.541 & .628 & .162 & 4.047 & .000 \\
\hline \multirow{3}{*}{2} & (Sabit) & 76.962 & 2.371 & & 32.458 & .000 \\
\hline & ÖSL & 1.855 & .825 & .118 & 2.247 & .025 \\
\hline & OYK & 1.265 & .988 & .067 & 1.281 & .201 \\
\hline \multirow{4}{*}{3} & (Sabit) & 73.083 & 2.477 & & 29.504 & .000 \\
\hline & ÖSL & 2.126 & .814 & .136 & 2.613 & .009 \\
\hline & OYK & .978 & .974 & .052 & 1.004 & .316 \\
\hline & Okul Türü & 1.673 & .360 & .183 & 4.642 & .000 \\
\hline \multirow{5}{*}{4} & (Sabit) & 70.978 & 2.518 & & 28.187 & .000 \\
\hline & ÖSL & 2.271 & .807 & .145 & 2.816 & .005 \\
\hline & OYK & 1.163 & .965 & .062 & 1.205 & .229 \\
\hline & Okul Türü & .302 & .517 & .033 & .585 & .559 \\
\hline & Okul & .637 & .174 & .208 & 3.670 & .000 \\
\hline \multirow{6}{*}{5} & (Sabit) & 85.112 & 2.729 & & 31.185 & .000 \\
\hline & ÖSL & 1.961 & .748 & .125 & 2.621 & .009 \\
\hline & OYK & 1.019 & .895 & .054 & 1.139 & .255 \\
\hline & Okul Türü & .561 & .479 & .061 & 1.169 & .243 \\
\hline & Okul & .469 & .162 & .154 & 2.902 & .004 \\
\hline & SED & -6.285 & .629 & -.364 & -9.992 & .000 \\
\hline
\end{tabular}

Aşamalı olarak elde edilen regresyon modellerinin tahmin gücünü belirlemek üzere $R$ ve $R^{2}$ değerleri incelendiğinde, tüm modellerin güçlü ve anlamlı ilişkiler gösterdiği anlaşılmaktadır [Model $1\left(R=.162, R^{2}=.026, p<.000\right)$, Model $2\left(R=.170, R^{2}=.029, p<.000\right)$, Model $3\left(R=.250, R^{2}=.062, p<.000\right)$, Model $4\left(R=.288, R^{2}=.083, p<.000\right)$ ve Model $5(R=.462$, $\left.\left.R^{2}=.213, p<.000\right)\right]$. Tablo 3 incelendiğinde, Öğretmen Sınıf Liderliğinin öğrencinin okul başarıs1 üzerindeki etkisi beş modelde de doğrulanmaktadır. Okul türü değişkeni, üçüncü modelde istatistiksel olarak anlamlı etkiye sahipken, dördüncü modelde okul değişkeninin modele dâhil edilmesi ile birlikte istatistiksel anlamını kaybetmiştir. Okuldan kaynaklanan ancak okul türünün açıklayamadığı etkiyi belirleyebilmek amacıyla okuldaki öğrencilerin sosyoekonomik düzeyinin eklendiği beşinci bir regresyon modeli oluşturulmuştur. Standardize edilmiş regresyon katsayıları $(\beta)$ değerlendirildiğinde yordayıcı değişkenlerin öğrenci başarısına etkisinin sırasıyla; "sosyoekonomik düzey", "okul" ve "öğretmen sinıf liderliği” olduğu anlaşılmaktadır. Tüm değişkenlerin toplam varyans üzerindeki açıklama gücü .21 düzeyinde bulunmuştur. Regresyon katsayılarına ilişkin $t$ değerlerine göre, okul yaşam kalitesi ve okul türü değişkenlerinin genel modeldeki istatistiksel etkisi anlamlı bulunmamıştır.

Çoklu regresyon sonuçları doğrultusunda iki alternatif yapısal regresyon modeli oluşturulmuştur. Araştırmanın tüm değişkenlerinin dâhil edildiği birinci modele ve doğrusal regresyonun anlamlı sonuç verdiği değişkenlerin dâhil edildiği ikinci modele ilişkin yapısal regresyon modelleri ve regresyon değerleri Şekil 1'de verilmiştir. 

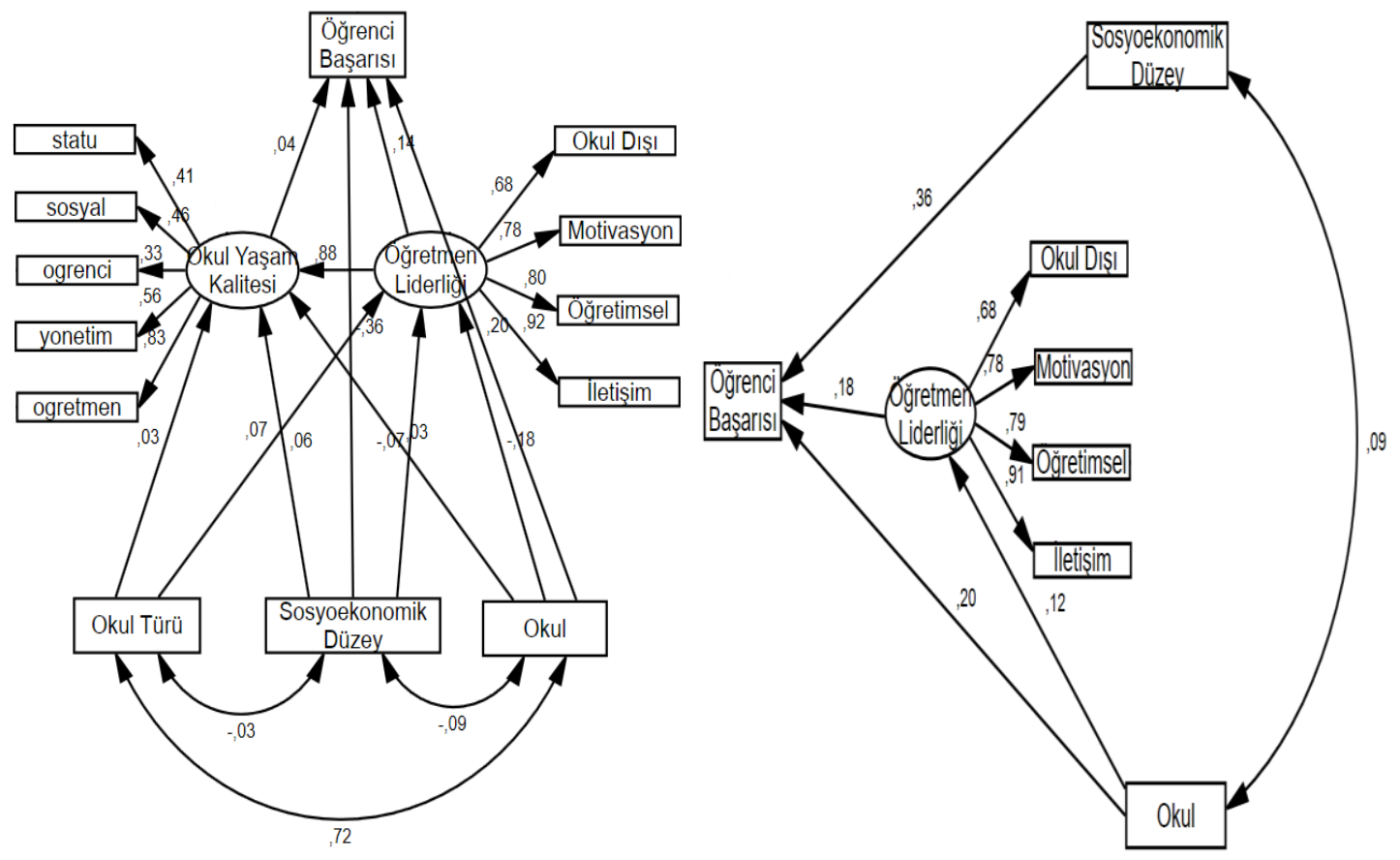

Şekil 1. Alternatif Yapısal Regresyon Modelleri

Şekil 1'de yer alan yapısal eşitlik modellerinin yol katsayıları incelendiğinde, doğrusal regresyonla elde edilen bulguların daha güçlü bir istatistiksel model olan yapısal regresyon modelinde de doğrulandığ görülmektedir. Tüm değişkenlerin dahil edildiği birinci modelin uyum değerleri $\left[\chi^{2} / s d=3.13\right.$; GFI=.96; CFI=.96; NFI=.94; RMSEA=.06] kabul edilebilir düzeydedir. Buna karşın doğrusal regresyonun anlamlı sonuç verdiği değişkenlerin test edildiği alternatif modele ilişkin uyum değerleri $\left[\chi^{2} / s d=1.99\right.$; GFI=.99; CFI=.99; NFI=.99; RMSEA=.04] mükemmel düzeydedir. Uyum değerlerinin mükemmel düzeyde bulunduğu alternatif modele göre, öğrenci başarısı üzerinde en etkili değişkenin sosyoekonomik düzey değişkeni olduğu görülmektedir $(\beta=.36 ; \mathrm{p}<.01)$. Öğrenci başarısı üzerinde ikinci etkili değişken okul değişkeni ( $\beta=.20 ; \mathrm{p}<.01)$, üçüncü etkili değişken ise öğretmen sınıf liderliği değişkenidir $(\beta=.18 ; \mathrm{p}<.01)$. Okul değişkeninin öğretmen sınıf liderliği değişkenin üzerinden dolaylı etkisi $(.12 * .18=.02$; $p<.01)$ düzeyinde bulunurken okul türü değişkeninin dolaylı etkisi anlamlı bulunmamıştır. Buna göre öğretmenlerin sınıf liderliği düzeylerinin açıklanmasında okul türü değişkenin anlamlı bir etki göstermediği söylenebilir.

\section{Tartışma, Sonuç ve Öneriler}

$\mathrm{Bu}$ araştırmada okul, öğretmen ve ailelerin sosyoekonomik düzeyleriyle ilgili değiş̧kenlerin öğrenci başarısı üzerindeki etkilerini karşılaştırmalı olarak ortaya koymak amaçlanmıştır. Öğretmen faktörünün başarı üzerindeki etkisini değerlendirmek üzere öğretmen sınıf liderliği, okul faktörünün etkisini değerlendirmek üzere öğrencilerin okul yaşam kalitesi algıları ile okul ve okul türü, aile faktörünün etkisini değerlendirmek üzere ailelerin sosyoekonomik düzeyi, öğrenci başarısını değerlendirmek üzere öğrencilerin okul başarı puanları incelenmiştir. Değişkenler arasındaki doğrudan ve dolaylı ilişkileri tanımlamak üzere oluşturulan yapısal regresyon modellerinin uyum indekslerinin iyi düzeyde olduğu görülmüştür. 
Araştırma sonuçlarına göre, öğretmen sınıf liderliğinin öğrenci okul başarısı üzerindeki etkisi, istatistiksel olarak, tüm regresyon modellerinde doğrulanmaktadır. Öğretmen sınıf liderliğinin öğrenci başarısı üzerindeki olumlu etkileri ile ilgili bu sonuç, alanyazındaki çok sayıda araştırma bulgularını da destekler niteliktedir (Kythreotis, Pashiardisve Kyriakides, 2010; Lipesa, 2018; Sugg, 2013). Öğretmen sınıf liderliğinin alt boyutları değerlendirildiğinde okul başarısı üzerindeki açıklayıcıllı̆ı en güçlü olan boyut iletişim boyutudur. Öğretmenin öğrencilerle kurduğu güçlü iletişim, onların okul başarıları üzerinde, okul dışı süreçlerdeki liderliğinden, motivasyon gücünden ve öğretimsel liderlik düzeyinden daha etkilidir. Ayrıca öğretmenlerin sınıf liderliği rollerinin öğrencilerin okul yaşam kalitesi algıları üzerinde de etkili olduğu görülmüştür. Bu sonuç, Sarı, Ötünç ve Erceylan'ın (2007) öğrencilerin okul yaşam kalitesini açıklama gücü en yüksek faktörün öğretmen faktörü olduğu bulgusu ile uyumludur. $\mathrm{Bu}$ sonuçlara göre, eğitim politikacıları tarafından öğretmenlerin mesleki yeterliklerin belirlenmesinde, sınıf liderliği becerilerinin daha güçlü vurgulanması gerektiği söylenebilir. Öğretmen sınıf liderliği, alt boyutlar bağlamında değerlendirildiğinde, öğretmenlerin iletişim becerilerinin öğretim becerilerinden daha önemli olduğu dikkat çekmektedir. Öğrenci başarısı üzerinde öğretmenlerin öğretimle ilgili teknik becerilerinden çok iletişim becerilerinin etkili olduğu söylenebilir. Buna göre hizmet öncesi ve hizmet içi eğitimlerde iletişim becerilerinin öneminin daha güçlü vurgulanması ve program içeriklerine yansıtılması önerilebilir.

Öğretmen sınıf liderliğinin aksine, okul yaşam kalitesi değişkeninin öğrenci başarısı üzerindeki etkisi istatistiksel olarak anlamlı bulunmamıştır. Alanyazında, okul yaşam kalitesinin öğrenci başarısı üzerindeki olumlu etkilerini ortaya koyan araştırma bulgularına (McLean ve Connor, 2015; Mok ve Flynn, 1997) karşın bu araştırmadaki etkisinin sınırlılığı dikkat çekici bir sonuçtur. Bununla birlikte, okul yaşam kalitesi algılarını, öğrencilerin okul başarıları ile ilişkisiz bulan çalışmalara da rastlanabilmektedir (Ainley ve Bourke, 1992). Bu sonuç, öğrencilerin okul yaşam kalitesinin önemli bir belirleyicisinin öğretmen boyutu olması ile açıklanabilir. Pek çok çalışma (Elitok-Kesici ve Türkoğlu, 2012; Sarı, 2012; Sarı, Ötünç ve Erceylan, 2007; KarabağKöse, 2019b) öğrencilerin okul yaşam kalitesi algılarını belirleyen en önemli faktörün öğretmen faktörü olduğunu göstermektedir. Bu araştırmanın bulguları da bu sonuçlarla uyumludur. Buna göre, öğretmenle doğrudan ilgili olan öğretmen liderliği faktörünün başarı üzerindeki yüksek etkisinin, okul yaşam kalitesi algılarını belirleyen öğrenci, yönetim, okul ortamı gibi diğer faktörlerin etkisini azalttığı ileri sürülebilir. Bu bulgu, öğretmen liderliğinin ve güçlü öğretmen öğrenci etkileşiminin öğrenci başarısı üzerindeki etkilerini ortaya koyan çalışmaları (Kythreotis, Pashiardisve Kyriakides, 2010; O'Connor ve McCartney, 2007; Sugg, 2013) destekler niteliktedir. Bu sonuca göre, okul düzeyli uygulamalarda okul yönetimlerinin önceliği okulun fiziksel kapasitesinden ziyade, öğretmen niteliklerini iyileştirici çalışmalara vermeleri önerilmektedir.

Öğretmen liderliği, okul yaşam kalitesi, okul türü, okul ve ailelerin sosyoekonomik düzeyi değişkenleri bütüncül bir modelde değerlendirildiğinde, öğrencilerin okul başarısı üzerindeki etkisi en güçlü olan değişken, ailelerin sosyoekonomik düzeyi değişkenidir. Oluşturulan doğrusal regresyon modelinde "okul türü" değişkeni istatistiksel olarak anlamlı etkiye sahipken, okul değişkeninin modele dahil edilmesi ile birlikte istatistiksel anlamını kaybetmiştir. Buna göre sosyoekonomik eşitsizliklerin başarı üzerindeki olumsuz etkilerini azaltmada en önemli faktörün öğretmen liderliği olduğu, buna karşın okul yaşam kalitesi ile ilgili faktörlerin başarıya etkisinin daha sınırlı olduğu görülmektedir. Özellikle PISA 
araştırmalarının sonuçları, okul türünün öğrenci başarısı açısından önemli bir belirleyici olduğunu göstermektedir (EARGED, 2004; OECD, 2017). Liseye geçiş ve üniversite yerleştirme sınavları için de benzeri bir durum söz konusudur. ÖSYM istatistiklerinde (2016) okul türüne göre sınav başarıları incelendiğinde lise türleri arasında özellikle fen liseleri ve sosyal bilimler liseleri lehine önemli bir farklılaşma olduğu görülmektedir. Benzeri şekilde, Cansız, Ozbaylanlı ve Çolakoğlu (2019) tarafından yapılan araştırma da okul türünün öğrencilerin sınav başarıları üzerindeki etkilerini ortaya koymaktadır. Genel ortalamalara dayalı bu verilerden farklı olarak, bu araştırma örnekleminde yer alan, anadolu lisesi, fen lisesi, imam hatip lisesi ve meslek lisesi olmak üzere dört farklı türdeki ve farklı sosyoekonomik düzeylerdeki okullarda, okul başarısı üzerinde okul türünün değil okul faktörünün ve ailelerin sosyoekonomik düzeyinin daha belirleyici olduğu görülmektedir. Bu çalışmada ise okuldan kaynaklanan ancak okul türünün açıklayamadığı etkiyi belirleyebilmek amacıyla oluşturulan alternatif doğrusal regresyon modeli, ailelerin sosyoekonomik düzeyinin öğrenci başarısını en güçlü açıklayan değişken olduğunu ortaya koymaktadır. Buna göre her okul türünde başarılı ve başarısız okulların varlığından söz edilebilirken başarıyı etkileyen en önemli faktör öğretmen ve sosyoekonomik düzey faktörleridir. Özellikle sosyoekonomik düzeyin öğrenci başarısı üzerindeki etkileri de pek çok araştırmacı tarafindan desteklenen bir sonuçtur (Engin-Demir, 2009; Özdemir ve Gelbal, 2014; Sarıer, 2016; Yelgün ve Karaman, 2015). Bu sonuçlara göre, akademik başarıya odaklı politik tedbirlerde sosyoekonomik düzey ve öğretmenle ilgili unsurların okul yaşam kalitesi, okul türü gibi okulla ilgili unsurlardan daha önemli olduğu göz ard1 edilmemelidir. $\mathrm{Bu}$ bağlamda özellikle okullar arasındaki sosyoekonomik eşitsizlikleri giderici tedbirlerin alınması önem taşımaktadır. Sosyoekonomik eşitsizlikler giderilmeden ve öğretmen niteliğini iyileştirmeden okula yapılacak diğer yatırımların başarı üzerindeki etkisinin sınırlılığı, eğitim politikacıları açısından dikkate alınması gereken en önemli sonuçlardan birisidir. Bu kapsamda, sosyoekonomik düzeyin öğrenci başarısı üzerindeki olumsuz etkilerini azaltmak üzere, her okulun öğrenci profilini çok iyi tahlil ederek gerekli sosyal destek mekanizmalarını okul düzeyinde ve yerel düzeyde harekete geçirmesi önerilebilir. Spesifik örneklem üzerinde yapılan bu ampirik çalışmanın sonuçları, öğrenci başarısını etkileyen faktörlerle ilgili kitlesel sonuçlar ortaya koyan ÖSYM, PISA, LGS gibi sınavlara dayalı yapılan araştırmalarla nispeten farklılaşmaktadır. Söz konusu farklılaşmayı derinlemesine inceleyen daha ileri araştırmalar yürütülebilir. Buna göre özellikle okul türü ve sosyoekonomik farklılıkların kontrol edildiği daha geniş kapsamlı ampirik araştırmalara ihtiyaç olduğu söylenebilir. 


\section{Kaynakça}

Ainley, J. ve Bourke, S. (1992). Student views of primary schooling. Research Papers in Education 7(2), 107-128. doi: 10.1080/0267152920070202

Argon, T. ve Kösterelioğlu, M. (2009). Üniversite öğrencilerinin üniversite yaşam kalitesi ve fakülte kültürüne ilişkin algıları. Elektronik Sosyal Bilimler Dergisi, 8(30), 43-61.

Avolio, B.J., Walumbwa, F.O., ve Weber, T.J. (2009). Leadership: Current theories, research, and future directions. Annual Review of Psychology, 60, 421-449.

Bakioğlu, A. (1998). Lider öğretmen. Marmara Üniversitesi Atatürk Eğitim Fakültesi Eğitim Bilimleri Dergisi, 10(10), 11-19.

Beycioğlu, K. ve Aslan, B. (2010). Öğretmen liderliği ölçeği: Geçerlik ve güvenirlik çalışması. İlköğretim Online, 9(2), 764-775.

Bilgiç, S. (2009). İlköğretim öğrencilerinde okul yaşam kalitesi algısının arkadaşlara bağlllık ve empatik sınıf atmosferi değişkenleriyle ilişsisinin incelenmesi. Yayımlanmamış yüksek lisans tezi. Çukurova Üniversitesi, Sosyal Bilimler Enstitüsü, Adana

Cansız, M., Ozbaylanlı, B. ve Çolakoğlu, M. H. (2019). Okul türünün öğrenci başarısı üzerindeki etkisi. Eğitim ve Bilim, 44(197), 275-314. doi:10.15390/EB.2019.7378

Cheong-Cheng, Y. (1994). Teacher leadership style: A classroom-level study. Journal of Educational Administration, 32(3), 54-71. doi: 10.1108/09578239410063111

Çalışma ve Sosyal Güvenlik Bakanlığı. (2016). Beceriler önemlidir: yetişkin becerileri araştırmasının kapsamlı sonuçları: Türkiye ülke notu [Çevrim-içi: https://www.oecd.org/skills/piaac/SkillsMatter-Turkey-Turkish-version.pdf] erişim tarihi: 07.06.2018.

Demir, Ö., Kaya, H. İ. ve Metin, M. (2012). Lise öğrencilerinde okul kültürünün bir öğesi olarak yaşam kalitesi algısının incelenmesi. Pegem Eğitim ve Öğretim Dergisi, 2(4), 9-28.

EARGED. (2004). Öğrenci başarısıını belirleme programı ulusal ön rapor. Ankara: MEB.

Elitok Kesici, A. ve Türkoğlu, A. (2012). Ortaöğretim kurumlarının okul yaşam kalitesi düzeyi ve ortaöğretim öğretmenlerinin sınıf içi iletişimde kullandıkları örtük davranışlar. Pamukkale Üniversitesi Eğitim Fakültesi Dergisi, 31(1), 149-162.

Engin-Demir, C. (2009). Factors influencing the academic achievement of the Turkish urban poor. International Journal of Educational Development, 29, 17-29.

Epstein, L.J. ve Mcpartland, J.M. (1976). The Concept and measurement of the quality of school life. American Educational Research Journal, 13(1), 15-30.

Ereş, F. ve Bilasa, P. (2017). Middle school students' perceptions of the quality of school life in Ankara. Journal of Education and Learning, 6(1), 175-183. doi: 10.5539/jel.v6n1p175

Ertesvåg, S. K. (2009). Classroom leadership the effect of a school development programme. Educational Psychology, 29(5), 515-539.

Karabağ-Köse, E. (2018). Öğretmen sınıf liderliği ölçeği öğretmen formu geçerlik ve güvenirlik çalışması. Milli Eğitim Dergisi, 47(220), 5-18.

Karabağ-Köse, E. (2019a). Öğretmen sınıf liderliği ölçeğinin (ÖSLÖ) geliştirilmesi ve psikometrik özellikleri. Kuram ve Uygulamada Eğitim Yönetimi, 25(1), 139-168. doi: 10.14527/kuey.2019.004.

Karabağ-Köse, E. (2019b). Dezavantajlı bölge okullarında öğrenim gören risk altındaki öğrencilerin okul bağl1lıklarını etkileyen faktörler. Eğitim ve Bilim (Baskı düzenlemesinde).

Karalar, M., Öksüz, Y. ve Baba-Öztürk, M. (2017). Ortaokul öğrencilerinin okul yaşam kalitesi algıları: demografik bir inceleme. Akademik Sosyal Arasttrmalar Dergisi, 5(52), 430-442.

Karatzias, A., Power, K.G. ve Swanson, V. (2001). Quality of school life: Development and preliminary standardisation of an instrument based on performance indicators in Scottish secondary schools. School Effectiveness and School Improvement, 12(3), 265-284. 
Kythreotis, A., Pashiardis, P. ve Kyriakides, L. (2010). The influence of school leadership styles and culture on students' achievement in Cyprus primary schools. Journal of Educational Administration, 48(2), 218-240.

Leonard, C. A. R. (2002). Quality of school life and attendance in primary schools. Yayımlanmamış doktora tezi. Newcastle Üniversitesi, Newcastle.

Lipesa, H. A. (2018). The role of teacher leadership in student achievement in mathematics. SSRN Electronic Journal. doi: 10.2139/ssrn.3276372.

McLean, L. ve Connor, M. C. (2015). Depressive Symptoms in Third-Grade Teachers: Relations to Classroom Quality and Student Achievement. Child Development, 86(3), 945-954. doi: $10.1111 /$ cdev. 12344

Mok, M. M. C. ve Flynn, M. (2002). Determinants of students' quality of school life: A path model. Learning Environments Research, 5(3), 275-300.

Mok, M. C. ve Flynn, M. (1997). Quality of school life and students' achievement in the HSC: A multilevel Analysis. Australian Journal of Education, 4l(2), 169- 188. doi: 10.1177/000494419704100206.

Muijs, D. ve Harris A. (2007). Teacher leadership (in)action: Three case studies of contrasting schools. Educational Management Administration \& Leadership, 35(1), 111-134.

O'Connor E. ve McCartney K. (2007). Examining teacher-child relationships and achievement as part of an ecological model of development. American Educational Research Journal, 44, 340-369. doi:10.3102/0002831207302172

OECD. (2017). PISA 2015 results (Volume III): Students' well-being. Paris: PISA OECD Publishing. doi: $10.1787 / 9789264273856$-en

ÖSYM. (2016). Ortaöğretim Kurumlarına göre 2016 öğrenci seçme ve yerleştirme sistemi sonuçları kitabı. [Çevrim-içi: http://www.osym.gov.tr/TR,13413/bolum-1-ozet-tablolar-lys.html] erişim tarihi: 04.08.2018.

Özdemir, B. ve Gelbal, S. (2014). PISA 2009 sonuçlarına göre öğrenci başarısını etkileyen faktörlerin kanonik ortak etki analizi ile incelenmesi. Eğitim ve Bilim, 39(175), 41-57.

Özdemir, S., Kılınç, A. Ç., Öğdem, Z. ve Er, E. (2013). Eğitim fakültesi öğrencilerinin fakülte yaşamının niteliğine ilişkin memnuniyet düzeylerinin çeşitli değişkenler açısından incelenmesi. Yükseköğretim ve Bilim Dergisi, 3(3), 228-235. doi: 10.5961/jhes.2013.081

Pounder, S. J. (2006). Transformational classroom leadership: the fourth wave of teacher leadership? Educational Management Administration Leadership, 34, 533-545.

Sammons, P., Toth, K., \& Sylva, K. (2017). The drivers of academic success for 'bright' but disadvantaged students: A longitudinal study of AS and A-level outcomes in England. Studies in Educational Evaluation, 57, 31-41. doi: 10.1016/j.stueduc.2017.10.004

Sarı, M. (2012). Okul yaşamının değerlendirilmesi: Okul yaşam kalitesi ölçeğinin geçerlik ve güvenirliği. Hacettepe Üniversitesi Eğitim Fakültesi Dergisi, 42, 344-355.

Sarı, M., Ötünç, E. ve Erceylan, H. (2007). Liselerde okul yaşam kalitesi: Adana ili örneği. Kuram ve Uygulamada Ĕ̈itim Yönetimi, 50, 297-320.

Sarıer, Y. (2016). Türkiye'de öğrencilerin akademik başarısını etkileyen faktörler: Bir meta-analiz çalışması. Hacettepe Üniversitesi Eğitim Fakültesi Dergisi, 31(3), 609-627. doi: :10.16986/HUJE.2016015868

Sugg, S. A. (2013). The Relationship between teacher leadership and student achievement. [Çevrim-içi: https://encompass.eku.edu/etd/138] erişim tarihi: 18.07.2018.

TIMMS. (2015). TIMMS 2015 ulusal fen ve matematik ön raporu. [Çevrim-içi: http://timss.meb.gov.tr/wpcontent/uploads/TIMSS_2015_Ulusal_Rapor.pdf ] erişim tarihi: 22.07.2018. 
Watt, K. M., Huerta, J., ve Mills, S. J. (2010). Advancement Via Individual Determination (AVID) professional development as a predictor of teacher leadership in the United States. Professional Development in Education, 36(4), 547-562, doi: 10.1080/19415250903430122

Wenner, J. A. ve Campbell, T. (2017). The theoretical and empirical basis of teacher leadership a review of the literature. Review of Educational Research, 87(1), 134-171. doi: $10.3102 / 0034654316653478$

Yelgün, A. ve Karaman, İ. (2015). Düşük sosyoekonomik düzeydeki mahallede bulunan bir ilköğretim okulunda akademik başarıyı düşüren faktörler nelerdir? Eğitim ve Bilim, 40(179), 259-268. doi: 10.15390/EB.2015.2331

York-Barr, A. J. ve Duke, K. (2004). What do we know about teacher leadership? Findings from two decades of scholarship. Review of Educational Research, 74, 255-316. doi: $10.3102 / 00346543074003255$

Yıldırım, İ. (2000). Akademik başarının yordayıcısı olarak yalnızlık, sınav kaygısı ve sosyal destek. Hacettepe Üniversitesi Eğitim Fakültesi Dergisi, 18, 167-176.

Yıldırım K. (2009). Uluslararası öğrenci değerlendirme programı (PISA) 2006 yılı verilerine göre Türkiye'de eğitimin kalitesini belirleyen temel faktörler (Yayımlanmamış doktora tezi). Gazi Üniversitesi, Ankara. 


\section{Extended Abstract}

\section{Introduction}

School, teacher and parent variables are among the most important determinants of student success in school. In the present research, quality of school life, school type and school, teachers' class leadership, and socioeconomic level of parents was examined. Surveys in the literature reveal that teacher qualifications affect the academic achievement of students. The impact of teacher leadership on academic achievement has been highlighted in a number of studies. Likewise, quality of school life is one of the important variables affecting student achievement. Therefore, it is important to examine the relationship between the teacher classroom leadership and the quality of the students' school life and academic achievement in a holistic approach. Because of the close association of pupils with school achievement, variables of school type and socioeconomic level of families were included in the present study as control variables. In addition, school was taken as an analysis unit and school-based differentiation as a control variable was also examined. The study seems to be crucial for the comparative study of school and teacher effectiveness on student achievement, using school-related control variables. This conceptual framework it is aimed to examine the relationship between student achievement, teacher classroom leadership and perceptions of school life quality of students and control variables (school, school type and socioeconomic level of families) in high schools.

\section{Method}

The research is structured in the relational screening model. The sample of the research consists of 698 students randomly chosen from 12 different schools in lower, middle and upper socioeconomic levels determined by cluster sampling in high school in Balıkesir central and districts in the academic year of 2017/2018. The "Teacher Classroom Leadership Scale" and "School Life Quality Perception Scale for High School Students" was used in the collection of data. In the assessment of the student success, 2016/2017 school year achievement averages are taken. Explanatory and confirmatory factor analyzes were conducted to evaluate the validity and reliability of the measurement instruments used in the research. It is evaluated the normality and linearity assumptions of research data. In this frame, the kurtosis and skewness coefficients were examined, single and multiple normality evaluations and the multiple correlation situations between the variables were evaluated. The study utilized a structural regression model and stepwise multiple linear regression analyzes to assess the relationships between variables.

\section{Findings and Discussion}

The aim of the study was to compare the effects of variables related to socioeconomic levels of school, teacher and families on student achievement. In order to evaluate the effects of variables on student achievement, it is considered that teacher classroom leadership related to teacher factors and students' perceptions of school life quality, school type and school related to school factors and socioeconomic levels of students related to the family factors. The fit index of the structural regression model to define the direct and indirect relationships between the variables was found to be at a good level.

According to the results of the research, the effect of teacher classroom leadership on student achievement is confirmed in all regression models. However, the effect of quality of 
school life on student achievement was not significant. In the created linear regression model, the "school type" variable had statistically significant effect, however, with the addition of the school variable, the statistical meaning has been lost. According to this, it can be said that teacher leadership is the most important factor in reducing the negative effects of socioeconomic inequalities on success whereas the effect of variables related to school life quality is limited. Unlike the PISA and ÖSYM examinations based on general averages, in this research sample, 4 different types of socioeconomic levels, including anatolia high school, high school, imam hatip high school and vocational high school, socioeconomic level seems to be more decisive. The alternative linear regression model, which is designed to determine the effect of the school, which cannot be explained by the school type, reveals that the socioeconomic level of the families is the strongest explaining variable of student success. According to this, although the existence of successful and unsuccessful schools can be mentioned in every kind of school, the most important factor affecting success is teacher and socioeconomic level factors.

Although research findings reveal the positive effects of school life quality on student achievement in the literature, the limit of these effects in this research is remarkable.

This result can be explained by the fact that teachers are important determinant of students' perceptions of school life quality. As in many studies these research findings also show that the most important explanatory factor of school life quality is the teacher dimension. According to this, it can be argued that the high effect of the teacher leadership factor on the success, minimize the other effects of sub dimensions of quality of the school such as student, management, school environment. This finding supports the studies that demonstrate the effects of teachers' leadership and strong teacher-student interaction on student achievement. 